\title{
Reputation building and the lifecycle model of dividends
}

\author{
Thomas Flavin, Thomas O'Connor* \\ Department of Economics, Finance and Accounting, Maynooth University, National University of Ireland Maynooth, Maynooth, Co. Kildare, Ireland
}

\section{A R T I C L E I N F O}

\section{Keywords:}

Dividend payout

Lifecycle

Reputation building

Retained equity

Growth opportunities

\begin{abstract}
A B S T R A C T
We analyze the relationship between corporate dividend policy and firm lifecycle in a low-disclosure regime, where domestic firms have an incentive to use dividends to build capital market reputation among external investors. We use a range of lifecycle indicators from the extant literature and find that, as predicted by the lifecycle model, dividend payouts increase along the lifecycle until peaking in the mature stage. Furthermore, dividends are positively related to growth opportunities. In all lifecycle stages, firms with relatively larger growth opportunities pay relatively larger dividends. We find that firms in low-disclosure regimes, engage in reputationbuilding behaviour, not just in the early stages of their lifecycle but also in the mature stage.
\end{abstract}

\section{Introduction}

The lifecycle model of dividends postulates that a firm's dividend payout policy is a function of their lifecycle stage. Early empirical studies of dividend policy, though not explicitly focusing on the lifecycle model, identified key characteristics of dividendpaying firms that are consistent with the prediction of the lifecycle model. For example, studies by Fama and French (2001) and Grullon et al. (2005) offer indirect support for this model as they find dividend initiators exhibit mature tendencies; they are large, profitable, and have positive free cash flow for distribution to shareholders. Furthermore, Brockman and Unlu (2009) show that dividend-paying growth firms pay smaller dividends compared to dividend-paying mature firms.

DeAngelo et al. (2006) explicitly test the dividend-lifecycle relationship by employing a single lifecycle measure, namely the ratio of retained to total equity, RE/TE. They argue that as firms mature this ratio increases for two reasons. First, as firms grow and become profitable RE increases. Second, their reliance on contributed equity falls as their investment opportunity set diminishes, and this coupled with growing profitability means that firms can substitute retained for external equity. Based on a sample of U.S. firms, DeAngelo et al. (2006) present empirical evidence that corporate dividend payouts follow a distinct lifecycle pattern, with a positive monotonic relationship between RE/TE and the likelihood of paying a dividend. Mature firms with large RE/TE are most likely to pay a dividend. Subsequent studies show that this also applies to other developed markets (Denis and Osobov, 2008); and to the dividend amount and not just to the likelihood of paying a dividend (Brockman and Unlu, 2009).

A connected strand of literature relates corporate dividend policy to country-level institutions and disclosure standards. Beck et al. (2006) show that country-level institutional development is inversely related to financing obstacles, prompting firms to implement their own strategies to overcome these obstacles. Brockman and Unlu (2011) test the lifecycle-inclusive disclosure standards versions of the agency outcome and substitution models of dividends (La Porta et al., 2000) and find that the 'dividend-payout-disclosure standards' relationship is u-shaped. The probability of paying a dividend is highest when disclosure standards are either weak or strong. Where disclosure standards are weak, the costs of debt and equity capital are often prohibitively high (see Botosan, 1997; and Sengupta, 1998 for the link between disclosure quality and the cost of capital). In such countries, growth firms respond by

\footnotetext{
* Corresponding author.

E-mail address: Thomas.g.oconnor@mu.ie (T. O'Connor).
} 
establishing a history of paying large dividends to foster trust with outside investors and build capital market reputation. ${ }^{1}$ This reduces financing constraints and allows them to grow (Gan et al., 2013). ${ }^{2}$ Where disclosure standards are strong, the cost of capital is lower implying that firms have less need to engage in reputation-building strategies. Therefore, we should not be surprised that the lifecycle model of dividends receives empirical support in countries with high disclosure standards, e.g. DeAngelo et al. (2006) and Denis and Osobov (2008) among others. Interestingly, Brockman and Unlu (2011) report similar findings for low-disclosure regimes. They find that the likelihood of paying a dividend increases with RE/TE but do not address the issue of whether or not the dividend amount varies over the firm lifecycle. Shao et al. (2013) show that RE/TE is positively and statistically significantly related to being a dividend payer but statistically indistinguishable from zero using dividends-to-sales (the dividend amount), in countries where creditor rights are weak. It remains an unanswered question if the magnitude of dividends differs between mature and growth firms in countries with low-disclosure requirements, where dividends may be used to establish capital market reputation. Arguably it is the size of the dividend that provides the strongest signal of a firm's intent to protect prospective shareholders, thus incentivising firms with greater growth potential to pay larger dividends. ${ }^{3}$

In this paper, we build on these two strands of the literature to address two issues. Firstly, we test the lifecycle model of dividends using data from Korea, a country with low-disclosure standards relative to developed markets, focusing on both the likelihood of paying a dividend and the dividend amount. Secondly, we try to reconcile the dividend-lifecycle relationship with the reputationbuilding strategies pursued by firms in countries with weak institutions. Ignoring reputation-building motives, the extant literature suggests that mature companies pay larger dividends than growth companies. However, where these motives are strong, early-stage firms may potentially pay comparable or larger dividends than their more-established counterparts. In addition to the RE/TE ratio, we employ a range of lifecycle measures such as firm age, size- and industry-adjusted age, multiclass linear discriminant analysis, and the composite proxy developed by Dickinson (2011). To the best of our knowledge, no study of the lifecycle model of dividends to date has used this wide range of lifecycle indicators. Using more than one lifecycle proxy ensures that our findings are not driven by one specific lifecycle measure and allows us to assess the interpretation of some of these measures in a low-disclosure regime.

Korea, over our sample period, provides an ideal setting in which to test the lifecycle model of dividends given the potential interaction of corporate dividend policy and reputation-building strategies in this newly liberalised financial market. ${ }^{4}$ Though Korea officially opened up its stock market to foreign investors in 1992, restrictive ownership limits of 3\% for an individual and 10\% for aggregate foreign holding were initially applied. These restrictions were gradually unwound and finally abolished in May 1998 . Foreign ownership grew substantially over our sample period. In 1996, 11.5\% of outstanding shares were in foreign ownership and these accounted for $13 \%$ of market capitalisation and by the sample end of 2004 , the corresponding numbers were $22 \%$ and $42 \%$ respectively (Kim and Yi, 2015; Table 2).

Operating within a newly-liberalised and emerging market, indigenous firms had a strong incentive to engage in reputationbuilding strategies to reassure foreign investors as to their commitment to protect minority stakeholders and to overcome countrylevel barriers to investment. As a country, Korea has relatively low-disclosure standards. Its score of 68 places it in the bottom tercile of the CIFAR disclosure distribution. ${ }^{5}$ Furthermore, Korea's civil law origin provides relatively weak protection of minority shareholders with La Porta et al. (1998) showing that its Rule of Law and Efficiency of Judicial System scores (5.35 and 6 respectively) are well below the average for common-law countries (6.46 and 8.15 respectively) and far removed from the U.S. market (who scores 10 on each measure). However, Korean firms appear to invest relatively little in voluntary programs aimed at boosting their corporate governance (see for example, Black et al., 2014), ${ }^{6}$ opening up the possibility that Korean firms may use alternative bonding mechanisms (e.g. large dividend payouts) and/or combine dividends with governance to build reputation capital (see John et al., 2015).

Our results produce a number of interesting findings. Firstly, Korean firms engage in reputation-building behaviour. Firms with relatively larger growth opportunities tend to pay larger dividends, in contrast to the findings for firms in more developed, highdisclosure regimes. Secondly, reputation building through dividend payout policy is not the sole preserve of early-stage firms, but is also a characteristic of mature firms. Mature firms with relatively higher growth opportunities continue to pay higher dividends to signal to potential investors that they are committed to protecting external providers of capital. Overall, the evidence is consistent with the predictions of the lifecycle model of dividends, with dividends increasing over the lifecycle and peaking during the mature stage. This story emerges due to both growth- and mature-stage firms pursuing reputation-building strategies.

\footnotetext{
${ }^{1}$ Using dividend payouts to build external financing capacity is also highlighted by Masters et al. (2016). Using a sample of publicly-traded U.S. firms, they show that contrary to conventional wisdom, financially constrained firms pay dividends, and increase their dividend immediately prior to a SEO announcement.

${ }^{2}$ The notion that firms can build capital market reputation using dividend payout is not new. Campbell and Turner (2011) find evidence in support of the agency substitution model of dividends in Victorian Britain.

${ }^{3}$ Using large dividends to build reputation involves a trade-off for corporate insiders. Since expropriation risk is higher in countries with weak legal protection/ disclosure standards, insiders forgo large private gains by paying large dividends rather than retaining the funds. However, if this form of reputation building is effective in reducing firm-level financing constraints, corporate insiders gain as the value of their (legal) cash flow rights increases as firms fund growth opportunities. Outside investors are prepared to fund these growth opportunities as the dividend signal is deemed both costly (for insiders) and credible. The larger the dividend the more costly it is for corporate insiders, hence the larger the signal sent to outside investors. Doidge et al. (2004) model this trade-off for firms who cross-list in the U.S. and use Level 2/3 ADRs (or an ordinary listing) as a bonding device.

${ }^{4}$ Korea has been the focus of a number of influential single-country studies due to the quality of the data available (Black et al., 2006); and the variation of firm governance and business structures within the country (Baek et al., 2004; Bae and Goyal, 2010).

5 The CIFAR disclosure index captures the accounting disclosure standards in a given country by examining annual reports for the inclusion or exclusion of 85 key items.

${ }^{6}$ Doidge et al. (2007) show that firms with seemingly large incentives to undertake firm-specific improvements in governance may choose not to do so where financial and/or economic development is weak.
} 
Our paper proceeds as follows. Section 2 describes our four lifecycle proxies and contains a description of the data. Section 3 presents our empirical methodology and discusses our results. Finally, Section 4 concludes.

\section{Lifecycle proxies and other data}

\subsection{Lifecycle proxies}

There are many lifecycle proxies proposed in the extant literature. Recent work suggests lifecycle proxies can conflict with one another (Von Eije and Megginson, 2008; and Banyi and Kahle, 2014), implying that reliance on a single lifecycle proxy is potentially problematic and/or existing proxies may be open to alternative interpretations. We use four lifecycle proxy measures. First, following DeAngelo et al. (2006), we use the ratio of retained earnings to total equity (RE/TE) (or assets, RE/TA), where total equity (TE) is the sum of retained (RE) and contributed equity. The underlying premise is that young firms have little or no retained equity and rely on contributed (external) equity, resulting in low RE/TE ratios. In contrast, mature firms with positive net cash inflows from operations coupled with a diminishing investment opportunity set have greater access to internal funds (retained equity) and less need for contributed equity. Hence, mature firms are expected to have large RE/TE ratios.

Second, we employ the lifecycle proxy of Dickinson (2011). It classifies firms into one of five lifecycle stages, namely introduction (birth), growth, maturity, shake-out and decline based on the combined signs of net cash flows from operating, financing, and investing activities. Net cash flows can be positive or negative, resulting in eight possible cash flow combinations. ${ }^{7}$ Firm classification is grounded in economic theory. For example, firms in the introductory stage invest more than they divest, spend more cash than they can generate internally, and issue more capital than they retire/repurchase, resulting in negative net cash flows from investments and operations, and a positive net cash flow from financing. In our empirical application, we follow Faff et al. (2016) in combining the shake-out and decline stages.

Third, we use the multiclass linear discriminant analysis (MLDA) of Faff et al. (2016), to classify firms into one of four lifecycle stages. This approach initially follows Dickinson (2011) to allocate firms to a lifecycle stage but then refines the classification by performing linear discriminant analysis, such as:

$$
\text { Group }_{i}=\alpha_{0}+\alpha_{1} \mathrm{AGE}_{\mathrm{i}}+\alpha_{2} \mathrm{RE} / \mathrm{TE}_{\mathrm{i}}+\alpha_{3} \text { PROFIT }_{\mathrm{i}}+\alpha_{4} \mathrm{SGrowth}_{\mathrm{i}}+\varepsilon_{\mathrm{i}}
$$

where age is firm age, RE/TE is the ratio of retained to total equity, PROFIT is return on assets (EBIT/Assets), and SGrowth is one-year sales growth. Using these variables, MLDA provides maximum separation between the groups. A benefit that MLDA and Dickinson (2011) has over RE/TE is that it explicitly classifies firms into a lifecycle stage. In contrast, RE/TE provides no objective cut-off point to delineate between lifecycle stages. The MLDA overcomes some of the problems inherent in the Dickinson (2011) approach and hence is expected to yield a more accurate method of allocating firms to a lifecycle stage. ${ }^{8}$ Thus, MLDA is our preferred lifecycle indicator and is our main reference point.

Finally, and for completeness, we use firm age. Many papers have suggested that firm age is an imperfect lifecycle proxy. Rather than increase monotonically with maturity, the 'firm age-maturity' relationship is inverted u-shaped; by definition, new firms are young in age but are also more likely to fail meaning that young firms can occupy the introduction and decline lifecycle stages. The time required for firms to reach maturity varies across industries. An old firm is not necessarily a mature firm and similarly, a young firm may not be a growth firm. We use age plus industry- and size-adjusted age. Black et al. (2014) is our source for firm age and we follow Faff et al. (2016) in adjusting firm age by industry and size to account for cross-sectional age differences across industries and firm size. We implement the adjustments by, first, assigning firms to an industry based on 2-digit SIC codes. Second, for each industry, we sort firms into size-based quintiles. Then, age is regressed on industry and size dummies and we calculate the industry- and sizeadjusted firm age as the percentile rank of the residual from this age regression. Von Eije and Megginson (2008) suggest that firm age measures calendar age while RE/TE captures 'financial age'.

\subsection{Other variables}

From Worldscope, we source a full list of Korean firms, both dead and alive, over the period from 1996 to 2004 . Our sample stops in 2004 because we use the Black et al. (2014) corporate governance scores which are only available over this period. We exclude firms in the financial and utility industries and firms with negative total equity, missing retained equity, and missing control variables. Once we exclude firms with missing TE and RE, all firms have non-negative RE. Our final sample of firms is described in Table 1. There are 435 individual firms, providing 1810 firm-year observations. The vast majority (86\%) of firms are in manufacturing, 124 belong to a Chaebol (business group) and 18 are cross-listed in the United States. Of the 435 firms, 48 remain in the sample throughout, while 32 are in the sample for just a single-year. The number of firm-year observations peaks at 335 in 2001.

We measure dividend payout using dividends-to-sales, dividends-to-assets, and 'payer'. Dividends-to-sales (assets) are measured as total common dividends scaled by total sales (assets). 'Payer' is a binary dummy variable which equals one if the firm pays a dividend in year $\mathrm{t}$ and zero otherwise. It is common in empirical studies of dividend payout to control for firm-specific determinants

\footnotetext{
${ }^{7}$ See Appendix 1 for these eight cash flow combinations.

${ }^{8}$ Faff et al. (2016, pp. 98) provide a number of arguments as to why MLDA is a superior lifecycle classification system.
} 
Table 1

Sample and lifecycle descriptions.

This table summarizes our sample of firms. We report the number of firms by industry, the number of firm-year observations in total and for each year, and the number of firm-year observations by the number of firms. Industry is based on local Korea Republic industry codes mapped to U.S. 2-digit SIC. Financial and utility firms are excluded. Crosslist (Chaebol) refers to the number of firm-years in which firms are cross-listed in the United States of any cross-listing type (belong to a business group). The sample period is 1998-2004. Panel B reports the number of firm-year observations in each lifecycle stage and Panel C reports whether firms belong in one or multiple lifecycle stages over the sample period using multiclass linear discriminant analysis (MLDA), Dickinson (2011), and RE/TE lifecycle. The Dickinson (2011) lifecycle approach groups firm-years into one of four lifecycle stages, namely introduction, growth, maturity, and shake-out/decline. RE/TE lifecycle groups firm-years into one of three lifecycle stages, namely young, mature, and old. Panel D reports median RE/TE, RE/TA, firm age, MBA decile for each MLDA lifecycle stage. Panel D also reports the percentage of firms that are in the same lifecycle stage according to MLDA and Dickinson (2011).

Panel A: Number of observations by industry, year, firm, and firm-type

\begin{tabular}{|c|c|c|c|c|c|c|c|}
\hline Industry & \# firms & Year & \# obs & \# obs & \# firms & Firm type & \# obs \\
\hline Agriculture, forestry and fishing & 2 & 1998 & 151 & 1 & 32 & Chaebol & 124 \\
\hline Mining & 2 & 1999 & 182 & 2 & 52 & Crosslist & 18 \\
\hline Construction & 27 & 2000 & 320 & 3 & 82 & & \\
\hline Manufacturing & 373 & 2001 & 335 & 4 & 76 & & \\
\hline Wholesale trade & 20 & 2002 & 261 & 5 & 82 & & \\
\hline Retail trade & 7 & 2003 & 282 & 6 & 63 & & \\
\hline \multirow[t]{2}{*}{ Services } & 4 & 2004 & 279 & 7 & 48 & & \\
\hline & 435 & & 1810 & & 435 & & \\
\hline
\end{tabular}

Panel B: number of firm-years in each lifecycle stage and the number of lifecycle stages by firm

\begin{tabular}{|c|c|c|c|c|c|}
\hline \multicolumn{2}{|l|}{ RE/TE lifecycle } & \multicolumn{2}{|l|}{ Dickinson (2011) } & \multicolumn{2}{|c|}{ Multiclass Linear Discriminant Analysis (MLDA) } \\
\hline Young & 453 & Introduction & 152 & Introduction & 506 \\
\hline Mature & 905 & Growth & 412 & Growth & 193 \\
\hline \multirow[t]{3}{*}{ Old } & 452 & Mature & 760 & Mature & 681 \\
\hline & & Shake-out/decline & 486 & Shake-out/decline & 430 \\
\hline & 1810 & & 1810 & & 1810 \\
\hline \multicolumn{6}{|c|}{ Panel C: number of lifecycle stages by firm } \\
\hline \multicolumn{2}{|c|}{ RE/TE lifecycle } & \multicolumn{2}{|l|}{ Dickinson (2011) } & \multicolumn{2}{|c|}{ Multiclass Linear Discriminant Analysis (MLDA) } \\
\hline 1 stage & 228 & 1 stage & 83 & 1 stage & 179 \\
\hline 2 stages & 188 & 2 stages & 168 & 2 stages & 165 \\
\hline \multirow[t]{3}{*}{3 stages } & 19 & 3 stages & 134 & 3 stages & 76 \\
\hline & & 4 stages & 50 & 4 stages & 15 \\
\hline & 435 & & 435 & & 435 \\
\hline
\end{tabular}

Panel D: Relationship between lifecycle proxies and MBA by MLDA lifecycle stage

\begin{tabular}{llll}
\hline & Introduction & Growth & Mature \\
\hline RE/TE & 0.17 & 0.32 & 0.58 \\
RE/TA & 0.06 & 0.15 & 0.34 \\
Dickinson (2011) & $13.44 \%$ & $24.35 \%$ & $50.66 \%$ \\
Age & 28 & 32 & 35 \\
MBA decile & 5 & 6 & 71 \\
\hline
\end{tabular}

of this policy, and we control for firms' growth opportunities, corporate governance, total equity (as opposed to retained equity), firm size, cash holdings, profitability, asset tangibility, leverage, and cash flow uncertainty.

We use market-to-book of assets (MBA) to control for growth opportunities. Adam and Goyal (2008) show that a firm's investment opportunity set is best proxied by MBA. We calculate the rank decile MBA on an annual basis based on a 3-year average (including the current year). ${ }^{9}$ La Porta et al. (2000) show that dividends can be an outcome of, or substitute for, governance and hence we include the corporate governance scores of Black et al. (2014) in our analysis. Following DeAngelo et al. (2006), we include both RE/TE and the ratio of total equity to total assets (TE/TA) in our regressions to distinguish the impact of total equity financing (TE) from the composition of equity financing (RE/TE). They find that dividend payout is positively related to both retained and total equity and hence both the composition (RE/TE) and size (TE/TA) of total equity influences dividend payout. Firm size is the rank decile of assets (in dividends-to-sales regressions) and rank decile of sales (in dividends-to-assets regressions). Cash holdings is cash to assets, profitability is measured as operating income (EBIT) to book assets, asset tangibility is gross property plant and equipment (PPE) to assets, leverage is captured by total debt to book assets, and following Chay and Suh (2009), cash flow uncertainty is measured as the standard deviation of operating income to total assets over the most recent four years. Furthermore, we include a 'Chaebol' dummy

\footnotetext{
${ }^{9}$ Gan et al. (2013) capture the "reputation-building" effect using the rank decile of sales growth (using a 5-year median). We use three as opposed to five years to reduce the attrition rate in our sample.
} 
Table 2

Dividend payout and growth opportunities.

This table reports dividend payouts by level of growth opportunities for a sample of 435 Korea Republic firms over the period from 1998-2004. Growth opportunities are measured using market-to-book of assets (MBA). Dividend payout is measured using dividends-to-sales (\%) and dividends-to-assets (\%), as indicated. Panel A reports median dividend payout by MBA quartile. Panel B reports the level and percentage change in median dividend payout when firms transition across MBA quartiles. The number of transitions are reported in parentheses. Date' $t$ ' is the transition year. $\% \Delta$ is the percentage change in median dividend payout between dates $t$ 1 and $\mathrm{t}$.

Panel A: Dividend payout by MBA quartile

\begin{tabular}{llll}
\hline & MBA quartile 1 & MBA quartile 2 & MBA quartile 3 \\
\hline Div-sales (\%) & 0.29 & 0.50 & 0.51 \\
Div-assets (\%) & 0.21 & 0.51 & 0.79 \\
& & & 0.79 \\
\end{tabular}

Panel B: Change in dividend payout by transitions in MBA quartiles

\begin{tabular}{|c|c|c|c|c|c|c|c|c|c|}
\hline & \multicolumn{3}{|c|}{$\begin{array}{l}\text { MBA quartile } 1 \text { to } 2 \\
(68)\end{array}$} & \multicolumn{3}{|c|}{$\begin{array}{l}\text { MBA quartile } 2 \text { to } 3 \\
\text { (63) }\end{array}$} & \multicolumn{3}{|c|}{$\begin{array}{l}\text { MBA quartile } 3 \text { to } 4 \\
\text { (59) }\end{array}$} \\
\hline & $\mathrm{t}-1$ & $\mathrm{t}$ & $\% \Delta$ & $\mathrm{t}-1$ & $\mathrm{t}$ & $\% \Delta$ & $\mathrm{t}-1$ & $\mathrm{t}$ & $\% \Delta$ \\
\hline Div-sales (\%) & 0.42 & 0.46 & 9.52 & 0.33 & 0.42 & 27.27 & 0.45 & 0.78 & 73.33 \\
\hline Div-assets (\%) & 0.34 & 0.45 & 32.35 & 0.39 & 0.50 & 28.21 & 0.48 & 0.71 & 47.92 \\
\hline
\end{tabular}

which is one if the firm belongs to a business group and zero otherwise. There is little consensus on the payout policies of Chaebol and non-Chaebol (independent) firms. Gul and Kealey (1999) find no difference in dividend payout between the two groups, while Hwang et al. (2013) conclude that dividends paid by Chaebol firms are lower than independent firms. In all regressions, we include a full set of industry and time dummies. Appendix 2 describes all variables and presents summary statistics for our sample of firms.

Panel B of Table 1 reports the number of firm-year observations in each lifecycle stage according to MLDA, Dickinson (2011), and RE/TE lifecycle, while Panel C of Table 1 reports the mobility of firms across the lifecycle stages. We follow Owen and Yawson (2010) and partition firms into one of three lifecycle stages, namely young, mature, and old, using RE/TE (what we term RE/TE LC). Young (old) firms are the group of firms in the lowest (highest) RE/TE quartile. All other firms are classified as mature. Using MLDA, there are more firm-year observations in the introduction (506) and mature (681) stages than in growth and shake-out/decline lifecycle stages (193 in growth-stages and 430 in shake-out/decline-stages). Firms display considerable movement across lifecycle stages. 15 firms occupy all four lifecycle stages; 76 (165) occupy 3 (Aivazian et al., 2003) stages, while 179 firms remain in a single lifecycle stage. Based on Dickinson's classification, the number of firm-years is 152, 412, 760, and 486 in the introduction, growth, mature, and shakeout/decline stages, respectively. Similar to MLDA, we observe a strong propensity to transit across states with 50 firms appearing in all four stages over the sample period. Only 83 firms remain in one lifecycle stage throughout, with all the others displaying some mobility across the lifecycle spectrum. Some firms exhibit a simple lifecycle progression from birth to decline, but many do not. It is not uncommon to see firms move back along the lifecycle (e.g. mature stage followed by growth stage), or skip a stage altogether. Miller and Friesen (1984) observe similar lifecycle dynamics in their five-stage lifecycle model. Using RE/TE LC, the number of firm-years is 453, 905, and 452 in the young, mature, and old lifecycle stages, respectively, but the tendency to move across lifecycle stages is much less pronounced. There are 228 firms who occupy a single lifecycle stage and just 19 who occupy all three stages.

Using MLDA as a benchmark, Panel D compares the lifecycle classifications. As expected, the median RE/TE and RE/TA increase as firms progress along their lifecycles, peaking during the mature stage before declining again during the shake-out/decline phase. For the Dickinson measure, we present the percentage of overlapping firm-years with the MLDA classification and we find that the degree of overlap is relatively low. For example, only $13.44 \%$ of firm-years belong to both the introduction stage according to MLDA and Dickinson. The corresponding figures for growth, mature and shake-out/decline stages are $24.35 \%, 50.66 \%$ and $24.88 \%$, respectively. Interestingly, it is mature, and not growth firms which score highest in terms of growth opportunities. Firm age increases monotonically as firms mature. However, if we separate shake-out from decline firms, we observe the inverted u-shaped relation between firm age and lifecycle as anticipated.

Table 2 investigates if there is any preliminary evidence consistent with reputation building. Panels A and B classify firms by growth opportunity quartiles and present median dividend payouts for each. Panel A shows a strong positive relationship between growth opportunities and dividend payout, consistent with reputation building. Firms in the highest MBA quartile pay the largest dividends. Panel B shows that the transition of firms across MBA quartiles is associated with increasing dividend payouts. The largest increases are observed for firms transitioning from quartile 3 to 4 .

\section{Discussion of results}

\subsection{Preliminary analysis}

Table 3 groups firms into lifecycle stages using each of our four-lifecycle proxies. RE/TE LC allocates firms across three lifecycle 
Table 3

Dividend payout in each lifecycle stage.

This table reports median dividend payout by lifecycle stage. Lifecycle is proxied using multiclass linear discriminant analysis (MLDA), Dickinson (2011), RE/TE, and firm age. Dividend payout is either dividends-to-asset (\%) or dividends-to-sales (\%), as indicated. In Panel A, firms are classified into three lifecycle stages, namely young, mature, and old using RE/TE. RE/TE is the ratio of retained to total equity. MLDA classifies firms into one of four lifecycle stages (introduction, growth, mature, and shakeout/decline) using multiclass linear discriminant analysis. The Dickinson (2011) lifecycle approach groups firm-years into one of four lifecycle stages, namely introduction, growth, maturity, and shake-out/decline. In Panel D, firms are classified by firm age quartile.

Panel A: Dividend payout and lifecycle using RE/TE lifecycle stages

\begin{tabular}{|c|c|c|c|c|}
\hline & Young & Mature & & Old \\
\hline Div-sales (\%) & 0.00 & 0.56 & & 0.82 \\
\hline Div-assets (\%) & 0.00 & 0.53 & & 0.82 \\
\hline \multicolumn{5}{|c|}{ Panel B: Dividend payout and lifecycle using Dickinson (2011) lifecycle stages } \\
\hline & Introduction & Growth & Mature & Shake-out/decline \\
\hline Div-sales (\%) & 0.39 & 0.46 & 0.62 & 0.28 \\
\hline Div-assets (\%) & 0.37 & 0.44 & 0.54 & 0.26 \\
\hline \multicolumn{5}{|c|}{ Panel C: Dividend payout and lifecycle using MLDA lifecycle stages } \\
\hline & Introduction & Growth & Mature & Shake-out/decline \\
\hline Div-sales (\%) & 0.12 & 0.45 & 0.89 & 0.35 \\
\hline Div-assets (\%) & 0.09 & 0.48 & 0.92 & 0.27 \\
\hline \multicolumn{5}{|c|}{ Panel D: Dividend payout and lifecycle using age quartiles } \\
\hline & Age quartile 1 & Age quartile 2 & Age quartile 3 & Age quartile 4 \\
\hline Div-sales (\%) & 0.58 & 0.55 & 0.40 & 0.40 \\
\hline Div-assets (\%) & 0.63 & 0.52 & 0.38 & 0.33 \\
\hline
\end{tabular}

stages; namely young, mature and old. MLDA and Dickinson use four stages (introduction, growth, mature and shake-out/decline). Using firm age, we create age quartiles. Dividend payout is proxied using dividends-to-sales (\%), and dividends-to-assets (\%). MLDA, Dickinson, and RE/TE present a consistent story for the relationship between lifecycle stage and dividend payout policy. Dividend payout increases as firms mature, and mature/old firms pay the largest dividends of all firms. MLDA and Dickinson agree on the nature of the dividend-lifecycle relationship, although the differences in dividend payouts between lifecycle stages is more pronounced using the former. For example, using dividends-to-sales, the median growth firm pays almost the same dividend amount in both classification schemes. However, the median mature firm's dividend payout is 0.89 under MLDA, yet just 0.62 under Dickinson. The bottom rows of Table 3 indicate that dividend payouts fall as firms' age.

In Table 4 we show how dividends change for firms who transition between lifecycle stages. We focus on transitions from introduction to growth and growth to mature (old using RE/TE) lifecycle stages, and present transitions from quartiles 1 to 2, 2 to 3 , and 3 to 4, using firm age. The number of transition firms is reported in parentheses. In general, dividend payouts increase as firms advance along their lifecycle. The size of the dividend changes differs by transition type. Under MLDA, the largest increase in dividend payouts occurs when firms transition from the introduction to the growth stage. Interestingly, growth firms continue to increase dividends once they mature. Classifying firms according to Dickinson and RE/TE, the largest change in dividend payouts is observed when young/growth firms reach the mature stage. However, since growth firms always pay larger dividends once they mature, the analysis presented in Tables 3 and 4 present a version of the lifecycle model of dividends whereby mature firms pay larger dividends than growth firms, irrespective of the lifecycle measure employed.

\subsection{Regression based tests of the lifecycle model of dividends}

We estimate dividend payout regressions for the dividend amount (Eq. (1)) and the likelihood of a firm paying a dividend (Eq. (2)). The equations are specified as follows:

$$
\begin{aligned}
& \operatorname{Div}_{i t}=\alpha_{1}+\alpha_{2} \text { LIFE }- \text { CYCLE }_{i t}+\beta \text { Controls }_{i t}+\text { Year }_{t}+\text { Industry }_{i}+e_{i t} \\
& \text { Prob }\left(\text { Payer }_{i t}=1\right)=F\left(\alpha_{1}+\alpha_{2} \text { LIFE }- \text { CYCLE }_{i t}+\beta \text { Controls }_{i t}+\text { Year }_{t}+\text { Industry }_{i}\right.
\end{aligned}
$$

The dividend amount equations are estimated using ordinary least squares with standard errors clustered by firms (Petersen, 2009), while the payer specification is estimated using logistic regression methods. Each regression contains a full set of firm, industry and time controls. We include the MBA decile in our regressions to capture reputation-building and not lifecycle effects per se, even though finance theory implies that MBA falls as firms mature. ${ }^{10}$

Table 5 presents our coefficient estimates from estimating Eq. (1) using dividends-to-sales (\%) and dividends-to-assets (\%). We estimate Eq. (1) separately for each of our lifecycle proxies. The estimated coefficient for RE/TE (and RE/TA, unreported) is positive

\footnotetext{
${ }^{10}$ A concern is RE/TE may be correlated with MBA and other variables capturing lifecycle effects. However, in our sample, the correlations between these variables are small (e.g. the correlation between RE/TE and MBA is just 0.13) which may explain why MBA and RE/TE are simultaneously statistically significant in our tests. One-year sales growth is not included in our regressions as sales growth and MBA are highly correlated.
} 
Table 4

Lifecycle transitions and change in dividend payout.

This table reports median dividend payout as firms' transition across lifecycle stages. Date' $\mathrm{t}$ ' is the transition year. Lifecycle is proxied using multiclass linear discriminant analysis (MLDA), Dickinson (2011), RE/TE, and firm age. Dividend payout is either dividends-to-sales (\%) or dividends-to-assets (\%), as indicated. In Panel A, firms are classified into three lifecycle stages, namely young, mature, and old using RE/TE. RE/TE is the ratio of retained to total equity. In Panel B, firms are classified into lifecycle stages using Dickinson (2011). Panel C uses MLDA. In Panel D, firms are classified by firm age quartile. The number of transitions is reported in parentheses. $\% \Delta$ is the percentage change in median dividend payout between dates $\mathrm{t}-1$ and $\mathrm{t}$.

Panel A: RE/TE quartile transitions and change in dividend payout

\begin{tabular}{|c|c|c|c|c|c|c|c|c|c|}
\hline & \multicolumn{4}{|c|}{$\begin{array}{l}\text { Young to mature } \\
\text { (41) }\end{array}$} & \multicolumn{5}{|c|}{$\begin{array}{l}\text { Mature to old } \\
\text { (26) }\end{array}$} \\
\hline & $\mathrm{t}-1$ & \multicolumn{2}{|l|}{$\mathrm{t}$} & $\% \Delta$ & \multicolumn{2}{|l|}{$\mathrm{t}-1$} & $\mathrm{t}$ & \multicolumn{2}{|l|}{$\% \Delta$} \\
\hline Div-sales (\%) & 0.20 & \multicolumn{2}{|l|}{0.49} & 145.0 & \multicolumn{2}{|l|}{0.60} & 0.79 & \multicolumn{2}{|l|}{31.7} \\
\hline Div-assets (\%) & 0.13 & \multicolumn{2}{|l|}{0.38} & 192.3 & \multicolumn{2}{|l|}{0.63} & 0.77 & \multicolumn{2}{|l|}{22.2} \\
\hline Panel B: Dickin & \multicolumn{4}{|c|}{$\begin{array}{l}\text { Introduction to growth } \\
\text { (14) }\end{array}$} & \multicolumn{4}{|c|}{$\begin{array}{l}\text { Growth to mature } \\
\text { (74) }\end{array}$} & \\
\hline & $\mathrm{t}-1$ & $\mathrm{t}$ & & $\% \Delta$ & $t-1$ & & $\mathrm{t}$ & $\% \Delta$ & \\
\hline Div-sales (\%) & 0.32 & 0.29 & & $(9.4)$ & 0.43 & & 0.45 & 4.7 & \\
\hline Div-assets (\%) & 0.37 & 0.43 & & 16.2 & 0.38 & & 0.49 & 28.9 & \\
\hline Panel C: MLDA & \multicolumn{4}{|c|}{$\begin{array}{l}\text { Introduction to growth } \\
\text { (39) }\end{array}$} & \multicolumn{4}{|c|}{$\begin{array}{l}\text { Growth to mature } \\
\text { (44) }\end{array}$} & \\
\hline & $\mathrm{t}-1$ & $\mathrm{t}$ & & $\% \Delta$ & $\mathrm{t}-1$ & & $\mathrm{t}$ & $\% \Delta$ & \\
\hline Div-sales (\%) & 0.18 & 0.36 & & 100.0 & 0.55 & & 0.66 & 20.0 & \\
\hline Div-assets (\%) & 0.22 & 0.43 & & 95.5 & 0.47 & & 0.80 & 70.2 & \\
\hline \multicolumn{10}{|c|}{ Panel D: Age quartile transitions and change in dividend payout } \\
\hline & \multicolumn{3}{|c|}{$\begin{array}{l}\text { Age quartile } 1 \text { to } 2 \\
\text { (48) }\end{array}$} & \multicolumn{3}{|c|}{$\begin{array}{l}\text { Age quartile } 2 \text { to } 3 \\
\text { (41) }\end{array}$} & \multicolumn{3}{|c|}{$\begin{array}{l}\text { Age quartile } 3 \text { to } 4 \\
(38)\end{array}$} \\
\hline & $\mathrm{t}-1$ & $\mathrm{t}$ & $\% \Delta$ & $\mathrm{t}-1$ & $\mathrm{t}$ & $\% \Delta$ & $\mathrm{t}-1$ & $\mathrm{t}$ & $\% \Delta$ \\
\hline Div-sales (\%) & 0.28 & 0.60 & 114.3 & 0.40 & 0.48 & 20.0 & 0.36 & 0.43 & 19.4 \\
\hline Div-assets (\%) & 0.23 & 0.70 & 204.3 & 0.35 & 0.47 & 34.3 & 0.25 & 0.37 & 48.0 \\
\hline
\end{tabular}

and significant which is consistent with the lifecycle hypothesis proposed by DeAngelo et al. (2006). The same pattern emerges when we use RE/TE LC, since we observe that firms in later lifecycle stages pay larger dividends. Simultaneously, the coefficient on TE/TA is positive and highly significant, which suggests that both total equity (TE/TA) and the retained proportion of total equity (RE/TE) matter for the dividend amount. These same dividend-lifecycle patterns emerge when we use MLDA, and to a lesser extent Dickinson, to proxy for lifecycle. RE/TE is excluded where lifecycle is proxied using MLDA because MLDA uses RE/TE to allocate firms to lifecycle stages. Table 5 also reports results for pairwise tests for differences in dividend payout policy across lifecycle stages. Using MLDA, the dividend payouts of mature firms are always statistically significantly larger than firms in the other lifecycle stages. Only, this classification procedure allows us to statistically distinguish between the dividends of mature and growth firms.

Using Dickinson, mature firms pay larger dividends (as a percentage of assets) than introduction and growth firms, although the differences in dividend payouts between the lifecycle stages are much lower than those recorded for the MLDA classification. Finally, the estimated coefficient for firm age is negative and statistically significant, implying that dividend payouts fall as firms' age. When we classify firms using either Dickinson or firm age and include RE/TE as a regressor, it retains its statistical significance. This finding suggests that the RE/TE variable may not be capturing all of the lifecycle effect or possibly it may be capturing a different effect.

As well as being statistically significant, these results are also economically significant and reveal large changes in dividends between lifecycle stages. Holding everything else constant, a one-standard deviation change in RE/TE (0.32) (which is approximately the difference in RE/TE between introduction and mature stage firms using RE/TE LC) changes dividends-to-sales by 0.13 or $17 \%$ of average dividend-to-sales. According to our results for the RE/TE LC classification, mature and old firms pay dividends which are, respectively, 1.91 and 2.30 times those paid by young firms. Dividends paid by old stage firms are approximately 1.2 times larger than dividends paid by mature stage firms or $14 \%$ of average dividends-to-sales. Using MLDA to classify firms to a lifecycle stage we seem similar patterns. Growth- and mature-stage firms pay dividends which are 1.19 and 1.61 times dividends paid by introductionstage firms. The difference in the dividend payouts of mature and growth stage firms is economically large and meaningful, with the dividends of mature stage firms being $0.18(0.21)$ larger than those paid by growth firms, which is $24 \%$ (31\%) of average dividendsto-sales (dividends-to-assets). The other classification systems, Dickinson and firm age, produce smaller differences but nonetheless, are economically significant. For example, using Dickinson, the difference between the dividends of mature and growth firms is $11 \%$ of average dividends-to-assets. The principal message that we can distil from these estimated coefficients is that the dividend payouts of mature stage firms are both statistically and economically larger than those of early-stage firms; two lifecycle stages where one might expect firms to use large dividends to build reputation capital.

Going beyond the lifecycle measure, we find that the estimated coefficient on the MBA decile variable is positive and statistically significant using dividends-to-sales and dividends-to-assets. This implies that firms with abundant growth opportunities pay large 
Table 5

Regression estimates of the dividend-lifecycle relationship.

This table reports pooled ordinary least squares estimates for the full sample of firms. The sample period is 1998 to 2004 . The dependent variable is dividend payout. Dividend payout is either dividends-to-sales (\%) or dividends-to-assets (\%), as indicated. The standard errors are clustered by firm. RE/TE is the ratio of retained to total equity. RE/TE LC classifies firms as young (bottom quartile), mature (second and third quartile), or old (top quartile), using RE/TE. MLDA classifies firms into one of four lifecycle stages (introduction, growth, mature, and shake-out/decline) using multiclass linear discriminant analysis. The Dickinson (2011) lifecycle approach groups firm-years into one of four lifecycle stages, namely introduction, growth, maturity, and shake-out/decline. Firm age is size and industry adjusted. Corporate governance is from Black et al. (2014). All other variables are defined in the text. Firm-growth is proxied using the market-to-book of assets (MBA). MBA decile is the rank decile of the average market-to-book of assets based on the previous three years. All regressions include an intercept term, industry and time dummies but are not reported. ***, **, and * denote statistical significance at the 1,5 , and $10 \%$ levels, respectively.

\begin{tabular}{|c|c|c|c|c|c|}
\hline & \multicolumn{5}{|l|}{ Lifecycle measure } \\
\hline & $\mathrm{RE} / \mathrm{TE}$ & RE/TE LC & MLDA & Dickinson (2011) & Firm age \\
\hline & \multicolumn{5}{|c|}{ Dependent variable is div-sales (\%) } \\
\hline $\mathrm{RE} / \mathrm{TE}$ & $0.401 * * *(4.49)$ & & & $0.410 * * *(4.61)$ & $0.405^{* * *}(4.59)$ \\
\hline Growth & & & $0.081 * * *(1.22)$ & $-0.000(0.00)$ & \\
\hline Mature & & $0.246 * * *(4.83)$ & $0.261 * * *(3.48)$ & $0.024(0.45)$ & \\
\hline Shake-out/decline & & & $0.037(0.66)$ & $0.061(1.12)$ & \\
\hline Old & & $0.351^{* * *}(4.37)$ & & & \\
\hline Firm age & & & & & $-0.0001^{* * *}(2.54)$ \\
\hline MBA decile & $0.069^{* * *}(6.80)$ & $0.070 * * *(6.83)$ & & $0.070^{* * *}(6.83)$ & $0.064 * * *(6.43)$ \\
\hline Corporate governance & $0.007 * *(2.05)$ & $0.007 *(1.90)$ & $0.013 * * *(3.33)$ & $0.007 * *(2.02)$ & $0.008 * *(2.16)$ \\
\hline Chaebol dummy & $-0.098(1.33)$ & $-0.103(1.38)$ & $-0.117(1.50)$ & $-0.095(1.29)$ & $-0.112(1.54)$ \\
\hline Size decile & $0.020(1.38)$ & $0.021(1.49)$ & $-0.013(0.94)$ & $0.019(1.35)$ & $0.021(1.46)$ \\
\hline Cash/assets & $0.432(1.07)$ & $0.497(1.24)$ & $1.182^{* *}(2.57)$ & $0.447(1.11)$ & $0.332(0.80)$ \\
\hline Profitability & $0.171(0.40)$ & $0.091(0.21)$ & & $0.191(0.45)$ & $0.090(0.21)$ \\
\hline TE/TA & $2.123 * * *(8.37)$ & $1.970 * * *(7.57)$ & & $2.108^{* * *}(8.42)$ & $2.187 * * *(8.67)$ \\
\hline Leverage & $0.182(0.82)$ & $0.108(0.48)$ & $-1.476 * * *(6.62)$ & $0.192(0.86)$ & $0.190(0.87)$ \\
\hline PPE/assets & $0.055(0.31)$ & $0.052(0.29)$ & $0.195(1.10)$ & $0.064(0.37)$ & $0.047(0.27)$ \\
\hline Cash flow uncertainty & $-1.064 * * *(4.45)$ & $-0.962^{* * *}(4.01)$ & $-1.192 * * *(4.83)$ & $-1.083^{* * *}(4.50)$ & $-1.038 * * *(4.28)$ \\
\hline Industry dummies & Included & Included & Included & Included & Included \\
\hline Time dummies & Included & Included & Included & Included & Included \\
\hline \# observations & 1810 & 1810 & 1810 & 1810 & 1810 \\
\hline R-squared & 0.343 & 0.343 & 0.240 & 0.344 & 0.349 \\
\hline Growth vs. mature & & & $* *$ & & \\
\hline \multirow[t]{2}{*}{ Mature vs. shake-out/decline } & & & $* * *$ & & \\
\hline & \multicolumn{5}{|c|}{ Dependent variable is div-assets (\%) } \\
\hline RE/TE & $0.329 * * *(4.26)$ & & & $0.342 * * *(4.47)$ & $0.334 * * *(4.40)$ \\
\hline Growth & & & $0.138 * *(2.41)$ & $-0.063(1.33)$ & \\
\hline Mature & & $0.209^{* * *}(4.63)$ & $0.346^{* * *}(5.69)$ & $0.013(0.27)$ & \\
\hline Shake-out/decline & & & $-0.010(0.20)$ & $0.021(0.45)$ & \\
\hline Old & & $0.314^{* * *}(4.43)$ & & & \\
\hline Firm age & & & & & $-0.0001 * * *(3.21)$ \\
\hline Industry dummies & Included & Included & Included & Included & Included \\
\hline Time dummies & Included & Included & Included & Included & Included \\
\hline Controls & Included & Included & Included & Included & Included \\
\hline \# observations & 1810 & 1810 & 1810 & 1810 & 1810 \\
\hline R-squared & 0.343 & 0.380 & 0.279 & 0.344 & 0.349 \\
\hline Growth vs. mature & & & $* * *$ & $*$ & \\
\hline Growth vs. shake-out/decline & & & $* * *$ & $* *$ & \\
\hline Mature vs. shake-out/decline & & & $* * *$ & & \\
\hline
\end{tabular}

dividends to build reputation and foster trust and strong bonds with external stakeholders and is consistent with results in Aivazian et al. (2003) for their sample of emerging market firms. Few of the control variables are statistically significant. The relationship between corporate governance and dividends is positive lending support to the agency outcome model of dividends. Cash flow uncertainty is negatively related to payout. As in Hwang et al. (2013), we find that Chaebol firms pay smaller dividends than nonbusiness group firms. Leverage and cash holdings are statistically significant determinants of dividend payout, only in the MLDA specification alone where MBA decile, firm size, RE/TE, and TE/TA are excluded. None of the other control variables appear to influence dividend payout policy.

Table 6 presents the marginal effects from the logit regression (Eq. (2)). ${ }^{11} \mathrm{RE} / \mathrm{TE}$ (and RE/TA, unreported) is always positive and a statistically significant determinant of the decision to pay a dividend. RE/TE LC confirms these findings by showing that mature firms are more likely to pay a dividend when compared to young firms (but not old firms). Different patterns emerge using MLDA and Dickinson. The former suggests that from growth through shake-out/decline, there is no statistical difference in the propensity to pay

\footnotetext{
${ }^{11}$ As a robustness test, we follow DeAngelo et al. (2006) and include an indicator variable which is 1 if the firm paid a dividend in the previous year. Estimated coefficients for RE/TE and RE/TA are reduced, sometimes by more than half, but they always remain statistically significant. Other variables are unaffected by its inclusion. Coefficients on the lagged dividend variable are always positive, consistent with the stylized fact that dividends tend to be sticky.
} 
Table 6

Payer regression estimates of the dividend-lifecycle relationship.

This table reports marginal effects from a series of logit regressions for the full sample of firms. The sample period is 1998 to 2004 . The dependent variable is divpayer, which is 1 if the firm pays a dividend in time t, zero otherwise. The standard errors are clustered by firm. The marginal effects are evaluated at the means of each variable. RE/TE is the ratio of retained to total equity. RE/TE LC classifies firms as young (bottom quartile), mature (second and third quartile), or old (top quartile), using RE/TE. MLDA classifies firms into one of four lifecycle stages (introduction, growth, mature, and shake-out/decline) using multiclass linear discriminant analysis. The Dickinson (2011) lifecycle approach groups firm-years into one of four lifecycle stages, namely introduction, growth, maturity, and shake-out/decline. Firm age is size and industry adjusted. Corporate governance is from Black et al. (2014). All other variables are defined in the text. Firm-growth is proxied using the market-to-book of assets (MBA). MBA decile is the rank decile of the average market-to-book of assets based on the previous three years. All regressions include an intercept term, industry and time dummies but they are not reported. ***, **, and * denote statistical significance at the 1,5 , and $10 \%$ levels, respectively.

\begin{tabular}{|c|c|c|c|c|c|}
\hline & \multicolumn{5}{|c|}{ Dependent variable is div-payer } \\
\hline & \multicolumn{5}{|l|}{ Lifecycle measure } \\
\hline & $\mathrm{RE} / \mathrm{TE}$ & RE/TE LC & MLDA & Dickinson (2011) & Firm age \\
\hline $\mathrm{RE} / \mathrm{TE}$ & $0.335 * * *(10.57)$ & & & $0.321 * * *(7.09)$ & $0.334 * * *(8.22)$ \\
\hline Growth & & & $0.115 * * *(8.03)$ & $0.010(0.35)$ & \\
\hline Mature & & $0.148^{* * *}(6.48)$ & $0.204 * * *(8.44)$ & $0.008(0.41)$ & \\
\hline Shake-out/decline & & & $0.064 * * *(4.47)$ & $-0.056 *(1.95)$ & \\
\hline Old & & $0.149 * * *(7.21)$ & & & \\
\hline Firm age & & & & & $0.000(0.86)$ \\
\hline MBA decile & $-0.002(0.86)$ & $-0.002(0.78)$ & & $-0.004(1.29)$ & $-0.002(0.74)$ \\
\hline Corporate governance & $0.002(1.45)$ & $0.001(1.20)$ & $0.001(1.10)$ & $0.002(1.56)$ & $0.001(1.43)$ \\
\hline Chaebol dummy & $0.009(0.50)$ & $0.001(0.06)$ & $0.003(0.12)$ & $0.008(0.44)$ & $0.011(0.59)$ \\
\hline Size decile & $0.011^{* * *}(2.95)$ & $0.014 * * *(3.25)$ & $0.011 * * *(2.25)$ & $0.011^{* * *}(2.76)$ & $0.011 * * *(2.84)$ \\
\hline Cash/assets & $0.076(0.68)$ & $0.143(1.10)$ & $0.383^{* * *}(3.18)$ & $0.060(0.54)$ & $0.085(0.77)$ \\
\hline Profitability & $1.169 * * *(4.46)$ & $1.362^{* * *}(4.77)$ & & $1.099 * * *(3.98)$ & $1.165^{* * *}(4.20)$ \\
\hline TE/TA & $0.295^{* * *}(4.05)$ & $0.317 * * *(3.85)$ & & $0.312^{* * *}(3.93)$ & $0.288^{* * *}(3.79)$ \\
\hline Leverage & $-0.093(1.33)$ & $-0.132 *(1.65)$ & $-0.381^{* * *}(5.23)$ & $-0.086(1.21)$ & $-0.093(1.35)$ \\
\hline PPE/assets & $-0.013(0.27)$ & $-0.014(0.24)$ & $0.041(0.70)$ & $-0.027(0.53)$ & $-0.014(0.29)$ \\
\hline Cash flow uncertainty & $-0.816^{* * *}(3.81)$ & $-0.863^{* * *}(3.44)$ & $-1.131 * * *(2.78)$ & $-0.780^{* * *}(3.77)$ & $-0.817 * * *(3.64)$ \\
\hline Industry dummies & Included & Included & Included & Included & Included \\
\hline Time dummies & Included & Included & Included & Included & Included \\
\hline \# observations & 1810 & 1810 & 1810 & 1810 & 1810 \\
\hline R-squared & 0.378 & 0.402 & 0.306 & 0.379 & 0.386 \\
\hline \multicolumn{6}{|l|}{ Growth vs. mature } \\
\hline Growth vs. shake-out/decline & & & & $* * *$ & \\
\hline Mature vs. shake-out/decline & & & & $* * *$ & \\
\hline
\end{tabular}

a dividend; and while the latter has a similar finding for growth and mature firms, it finds that firms in the shake-out/decline stage pay significantly lower dividends than earlier-stage firms.

The estimated coefficient on the MBA decile variable which is positive and statistically significant using the dividend amount, loses statistical significance in the dividend payer regressions. This implies that firms with relatively large growth opportunities are no more likely to pay dividends but when they do, they tend to be larger. In the payer regressions, size, profitability, cash-flow uncertainty, and to a lesser extent TE/TA, are consistent and reliable determinants of dividend payout, implying that larger firms with stable cash flows (profits) pay dividends. ${ }^{12}$

In Tables 7 and 8 we explore in detail the influence of growth opportunities (MBA) on dividend payouts, and in particular on the dividend-lifecycle relationship. In Table 7 we estimate Eq. (1) separately for each MLDA lifecycle stage and assess the influence of the MBA decile variable on dividend payouts in each lifecycle stage. In the bottom rows of Table 7, we report the proportion of the total explained variation in dividend payouts attributable to each variable. Interestingly while we find that our growth opportunities proxy is a statistically significant determinant of dividend payout in all four lifecycle stages, it exerts its largest influence in the mature lifecycle stage, with growth opportunities explaining almost one third of the total variation in dividend payouts. For firms in the growth stage, the corresponding figure is $20 \%$. Only TE/TA is more important than growth opportunities in explaining the variation in dividend payout in the growth and mature lifecycle stage. These findings suggest that firms with relatively large growth opportunities use dividends to build reputation capital regardless of lifecycle stage, and reputation building is not restricted to firms in the 'growth' lifecycle stage.

We explore this issue further by estimating separate dividend-lifecycle regressions for firms with above- and below-median growth opportunities (MBA). If reputation building through dividends is predominantly practiced by early-stage firms, then we might expect the differential in dividend payouts between mature and growth firms to be smaller for the group of firms with large growth opportunities compared to those with low growth opportunities, and relative to the whole sample. Table 8 reports our results and the observed pattern does not support this hypothesis. Irrespective of the level of growth opportunities, mature firms always pay larger dividends than firms in the introduction stage and, using dividends-to-assets, they also pay larger dividends than growth firms. The

\footnotetext{
${ }^{12}$ Appendix 3 presents results of robustness checks, which show that our dividend-lifecycle tests are robust to different MLDA specifications.
} 
Table 7

The determinants of dividend payout in each MLDA lifecycle stage.

This table reports separate pooled ordinary least squares estimates for each lifecycle stage. The sample period is 1998 to 2004 . The dependent variable is dividendsto-sales (\%). The standard errors are clustered by firm. Lifecycle stages are determined using multiclass linear discriminant analysis (MLDA). MLDA classifies firms into one of four lifecycle stages (introduction, growth, mature, and shake-out/decline) using multiclass linear discriminant analysis. RE/TE is the ratio of retained to total equity. Corporate governance is from Black et al. (2014). Firm-growth is proxied using the market-to-book of assets (MBA). MBA decile is the rank decile of the average market-to-book of assets based on the previous three years. All other variables are defined in the text. All regressions include an intercept term, industry and time dummies but are not reported. The bottom panel outlines the amount of the variation in dividend payout explained by each right hand side variable as a percentage of the variation in dividend payout explained by the right hand side variables as a whole. ***, **, and * denote statistical significance at the 1 , 5 , and $10 \%$ levels, respectively.

Dependent variable is div-sales (\%)

\begin{tabular}{|c|c|c|c|c|}
\hline & \multicolumn{4}{|c|}{ Lifecycle stage according to MLDA } \\
\hline & Introduction & Growth & Mature & Shake-out/decline \\
\hline MBA decile & $0.033^{* * *}(2.96)$ & $0.089 * * *(3.79)$ & $0.109 * * *(5.50)$ & $0.051 * * *(3.05)$ \\
\hline $\mathrm{RE} / \mathrm{TE}$ & $0.660 * * *(5.75)$ & $0.476 * * *(2.16)$ & $0.408 *(1.79)$ & $0.149(0.99)$ \\
\hline Corporate governance & $0.004(1.10)$ & $-0.010(1.36)$ & $0.014^{* *}(2.08)$ & $0.006(1.10)$ \\
\hline Chaebol dummy & $-0.079(0.90)$ & $-0.088(0.61)$ & $-0.137(0.94)$ & $-0.175(1.58)$ \\
\hline Size decile & $0.040 * * *(2.64)$ & $0.038 *(1.66)$ & $-0.013(0.44)$ & $0.021(0.84)$ \\
\hline Cash/assets & $0.398(0.82)$ & $-0.186(0.21)$ & $-0.003(0.01)$ & $2.480 * * *(2.85)$ \\
\hline Profitability & $0.008(0.02)$ & $-5.403 *(1.69)$ & $-0.376(0.34)$ & $5.928 * * *(4.02)$ \\
\hline TE/TA & $1.770^{* * *}(5.52)$ & $2.430 * * *(5.16)$ & $3.182^{* * *}(6.37)$ & $1.470 * * *(3.54)$ \\
\hline Leverage & $-0.120(0.55)$ & $-0.034(0.07)$ & $0.780(1.58)$ & $-0.262(0.64)$ \\
\hline PPE/assets & $0.240(1.47)$ & $0.126(0.32)$ & $-0.077(0.20)$ & $0.321(0.97)$ \\
\hline Cash flow uncertainty & $-0.170(0.38)$ & $-1.885^{* * *}(2.74)$ & $-0.597(1.33)$ & $-1.139 * * *(2.98)$ \\
\hline Industry dummies & Included & Included & Included & Included \\
\hline Time dummies & Included & Included & Included & Included \\
\hline \# observations & 506 & 193 & 681 & 430 \\
\hline R-squared & 0.284 & 0.336 & 0.329 & 0.306 \\
\hline \multirow[t]{3}{*}{ Median MBA decile } & 5 & 6 & 7 & 4 \\
\hline & \multicolumn{4}{|c|}{ Analysis of variance (ANOVA) } \\
\hline & Introduction & Growth & Mature & Shake-out/decline \\
\hline MBA decile & 6.31 & 20.28 & 32.82 & 13.41 \\
\hline $\mathrm{RE} / \mathrm{TE}$ & 39.05 & 7.13 & 4.05 & 1.21 \\
\hline Corporate governance & 0.76 & 3.12 & 5.77 & 1.61 \\
\hline Chaebol dummy & 0.70 & 0.54 & 1.14 & 3.50 \\
\hline Size decile & 5.18 & 2.87 & 0.30 & 1.19 \\
\hline Cash/assets & 0.67 & 0.09 & 0.00 & 25.94 \\
\hline Profitability & 0.00 & 3.65 & 0.10 & 18.05 \\
\hline TE/TA & 37.12 & 32.19 & 41.69 & 17.27 \\
\hline Leverage & 0.18 & 0.01 & 1.87 & 0.47 \\
\hline PPE/assets & 1.20 & 0.15 & 0.04 & 1.66 \\
\hline Cash flow uncertainty & 0.10 & 17.17 & 0.94 & 6.03 \\
\hline Industry dummies & 3.37 & 4.77 & 5.82 & 3.77 \\
\hline Time dummies & 5.36 & 8.03 & 5.47 & 5.88 \\
\hline
\end{tabular}

difference in dividend payouts between mature and growth stage firms is quantitatively the same across both sub-samples, $25.37 \%$ and $25.97 \%$ of average dividends-to-assets for above- and below median MBA firms respectively.

The key implication of these results, presented in Tables 7 and 8, is that reputation building serves to maintain, and not reduce, the difference in dividend payouts that exists between firms in growth and mature lifecycle stages. The predictions of the lifecycle model of dividends continue to hold in this relatively low-disclosure regime because all firms, not just early-stage firms, engage in reputation building through dividend policy to earn the trust and confidence of external investors.

\section{Conclusion}

We analyze the influence of reputation building on the dividend-lifecycle relationship in a low-disclosure regime where firms have strong incentives to implement confidence building corporate policies aimed at overcoming country-level obstacles to external investment. Since DeAngelo et al. (2006), scaled measures of retained equity, RE/TE and RE/TA, have been widely used as firm lifecycle indicators in the literature. However, this result is based on a sample of U.S. firms. Supporting international evidence from Denis and Osobov (2008) also comes from developed financial markets with high-disclosure requirements and strong investor protection. Here, we focus on the dividend payout-lifecycle relationship for Korea during a period when Korea became financial liberalization and gradually removed all barriers to foreign investment. To better understand the evolution of dividends in a relatively low-disclosure environment, we utilise, not only the aforementioned RE/TE lifecycle indicator, but a range of such indicators drawn from the extant literature, such as firm age, Dickinson (2011) and the MLDA methodology of Faff et al. (2016). 
Table 8

The lifecycle model of dividends by level of growth opportunities.

This table examines the lifecycle model of dividends for firms with high MBA (above-median) and low MBA (below-median). Firm-growth is proxied using the market-to-book of assets (MBA). MBA decile is the rank decile of the average market-to-book of assets based on the previous three years. Panel A reports median dividend payout in each lifecycle stage by level of firm growth. Dividend payout is either dividends-to-sales (\%) or dividends-to-assets (\%), as indicated. Lifecycle stages are determined using multiclass linear discriminant analysis (MLDA). MLDA classifies firms into one of four lifecycle stages (introduction, growth, mature, and shake-out/decline) using multiclass linear discriminant analysis. Panel B reports separate pooled ordinary least squares estimates for firms classified as high (abovemedian) or low (below-median) MBA. The sample period is 1998 to 2004. The standard errors are clustered by firm. All regressions include an intercept term, control variables, industry and time dummies but are not reported. ***, **, and * denote statistical significance at the 1,5 , and $10 \%$ levels, respectively.

Panel A: Dividend payouts in each MLDA lifecycle stage by level of growth opportunities

\begin{tabular}{|c|c|c|c|c|}
\hline & \multicolumn{2}{|l|}{ High MBA } & \multicolumn{2}{|l|}{ Low MBA } \\
\hline & Div-sales (\%) & Div-assets (\%) & Div-sales (\%) & Div-assets (\%) \\
\hline Introduction & 0.06 & 0.06 & 0.19 & 0.10 \\
\hline Growth & 0.59 & 0.65 & 0.31 & 0.31 \\
\hline Mature & 1.16 & 1.16 & 0.66 & 0.66 \\
\hline Shake-out/decline & 0.31 & 0.29 & 0.37 & 0.27 \\
\hline \multicolumn{5}{|c|}{ Panel B: Regression based tests of the dividend-lifecycle model by level of growth opportunities } \\
\hline & \multicolumn{2}{|c|}{ Dependent variable is div-sales (\%) } & \multicolumn{2}{|c|}{ Dependent variable is div-assets (\%) } \\
\hline & High MBA & Low MBA & High MBA & Low MBA \\
\hline Growth & $0.102(1.06)$ & $0.026(0.29)$ & $0.199 * *(2.29)$ & $0.041(0.68)$ \\
\hline Mature & $0.261 * * *(2.34)$ & $0.169 * *(2.00)$ & $0.369 * * *(3.88)$ & $0.215^{* * *}(3.34)$ \\
\hline Shake-out/decline & $0.117(1.43)$ & $0.070(1.04)$ & $0.083(1.17)$ & $0.012(0.26)$ \\
\hline Industry dummies & Included & Included & Included & Included \\
\hline Time dummies & Included & Included & Included & Included \\
\hline Controls & Included & Included & Included & Included \\
\hline \# observations & 904 & 906 & 904 & 906 \\
\hline R-squared & 0.298 & 0.140 & 0.334 & 0.195 \\
\hline Growth vs. mature & & & * & $* *$ \\
\hline \multicolumn{5}{|l|}{ Growth vs. shake-out/decline } \\
\hline Mature vs. shake-out/decline & & & $* * *$ & $* * *$ \\
\hline
\end{tabular}

Focusing on the lifecycle model of dividends, the different classification methods tell a broadly similar story and are supportive of the model. Dividends increase across the lifecycle spectrum, peaking in the mature stage before falling in the final shakeout/decline stage. Dividend changes between lifecycle stages are large and economically significant, particularly for the transition from growthto mature-stage firms. However, reputation building also plays a significant role in determining the size of dividend payouts. Contrary to the premise underlying the adoption of RE/TE as a lifecycle indicator, we find that dividends are positively related to growth opportunities, implying that firms use dividend policy to reassure investors and thereby build reputation to overcome country-level institutional barriers to investment. Furthermore, the largest growth of dividends is observed for firms transitioning from the third to the fourth quartile of growth opportunities. Partitioning the sample into firms with above- and below-median growth opportunities (MBA), confirms this finding with the relatively higher growth group paying higher dividends and the differential between the dividend payouts of mature- and growth-stage firms persisting between groups. Therefore, it appears that reputation building is a motive for paying larger dividends for firms across all lifecycle stages and not solely associated with early-stage firms.

\section{Acknowledgements}

We thank the editor and referee for helpful and insightful comments on an earlier version of the paper. We thank Bernard Black, Burcin Yurtoglu and their colleagues for the use of their corporate governance data. Any remaining errors are entirely our own.

\section{Appendix}

\section{Appendix 1}

Dickinson (2011) lifecycle cash flow patterns classification scheme.

Dickinson (2011) lifecycle approach groups firm-years into one of five lifecycle stages, namely introduction, growth, maturity, shake-out, and decline. Each lifecycle stage is determined by the combined signs on net cash flow from operating, investing, and financing activities. There are eight different net cash flow permutations.

\begin{tabular}{llllllll}
\hline Net cash flow and predicted sign: & Intro & Growth & Mature & Shake-out & & Decline \\
\hline NCF from operating activities & - & + & + & - & + & + & - \\
NCF from investing activities & - & - & - & - & + & + & + \\
NCF from financing activities & + & + & - & - & + & - & + \\
\hline
\end{tabular}


Appendix 2

Variable descriptions.

\begin{tabular}{|c|c|c|c|c|c|c|c|}
\hline Variable & Description & Source & Mean & Median & $\begin{array}{l}\text { Std. } \\
\text { dev }\end{array}$ & Min & Max \\
\hline $\begin{array}{l}\text { Dividends- } \\
\text { to-assets } \\
\text { (\%) }\end{array}$ & Total common dividends to total assets & Worldscope & 0.67 & 0.45 & 0.77 & 0.00 & 4.09 \\
\hline $\begin{array}{l}\text { Dividends- } \\
\text { to-sales } \\
(\%)\end{array}$ & Total common dividends to net sales & Worldscope & 0.74 & 0.48 & 0.89 & 0.00 & 4.52 \\
\hline Payer & 1 if the firm pays a dividend in year $t, 0$ otherwise & Worldscope & 0.71 & 1.00 & 0.45 & 0.00 & 1.00 \\
\hline MBA & Three-year average market to book value of assets & Worldscope & 0.66 & 0.45 & 0.69 & 0.09 & 6.35 \\
\hline $\mathrm{RE} / \mathrm{TE}$ & Retained equity to total equity & Worldscope & 0.40 & 0.36 & 0.32 & 0.00 & 4.74 \\
\hline $\mathrm{RE} / \mathrm{TA}$ & Retained equity to book assets & Worldscope & 0.20 & 0.17 & 0.17 & 0.00 & 0.83 \\
\hline $\begin{array}{l}\text { MLDA } \\
\text { lifecycle }\end{array}$ & $\begin{array}{l}\text { Lifecycle measure using multiclass linear discriminant } \\
\text { analysis }\end{array}$ & Worldscope & n.m. & n.m. & n.m. & n.m. & n.m. \\
\hline $\begin{array}{l}\text { Dickinson } \\
\text { (2011) } \\
\text { lifecycle }\end{array}$ & Dickinson (2011) lifecycle measure & Worldscope & n.m. & n.m. & n.m. & n.m. & n.m. \\
\hline Age & Age of firm: year less establishment year plus 1 & $\begin{array}{l}\text { Black et al. } \\
(2014)\end{array}$ & 35.05 & 34.00 & 13.04 & 1 & 107 \\
\hline $\begin{array}{l}\text { Corporate } \\
\text { govern- } \\
\text { ance }\end{array}$ & Corporate governance index & $\begin{array}{l}\text { Black et al. } \\
\text { (2014) }\end{array}$ & 34.40 & 32.95 & 10.58 & 0.00 & 84.59 \\
\hline TE/TA & Ratio of total equity to book assets & Worldscope & 0.48 & 0.47 & 0.19 & $(0.04)$ & 0.88 \\
\hline Size & $\begin{array}{l}\text { Size rank decile using book assets (in div-sales and } \\
\text { governance regressions) and sales (in div-assets regressions) }\end{array}$ & Worldscope & n.m. & n.m. & n.m. & n.m. & n.m. \\
\hline Cash/assets & Ratio of cash to book assets & Worldscope & 0.12 & 0.08 & 0.10 & 0.00 & 0.64 \\
\hline Profitability & Ratio of earnings before interest and taxation to book assets & Worldscope & 0.03 & 0.03 & 0.06 & $(0.41)$ & 0.24 \\
\hline Leverage & Ratio of total debt to book assets & Worldscope & 0.28 & 0.28 & 0.17 & 0.00 & 0.76 \\
\hline PPE/assets & Ratio of property plant and equipment (PPE) to book assets & Worldscope & 0.41 & 0.41 & 0.17 & 0.00 & 0.86 \\
\hline $\begin{array}{l}\text { Chaebol } \\
\text { dummy }\end{array}$ & 1 if the firm belongs to business group in year t, 0 otherwise & $\begin{array}{l}\text { Black et al. } \\
\text { (2014) }\end{array}$ & 0.31 & 0.00 & 0.46 & 0 & 1 \\
\hline $\begin{array}{c}\text { Cash flow } \\
\text { uncer- } \\
\text { tainty }\end{array}$ & $\begin{array}{l}\text { Standard deviation of (operating income/total assets) over } \\
\text { the most recent four years }\end{array}$ & Worldscope & 0.05 & 0.03 & 0.08 & 0.00 & 1.29 \\
\hline $\begin{array}{l}\text { Industry } \\
\text { Dummies }\end{array}$ & Industry codes mapped to US 2-digit SIC codes & Worldscope & n.m. & n.m. & n.m. & n.m. & n.m. \\
\hline \multicolumn{8}{|c|}{ Lifecycle descriptors for Dickinson (2011) and MLDA: } \\
\hline Sales growth & One-year sales growth & Worldscope & 0.08 & 0.08 & 0.12 & $(0.36)$ & 0.50 \\
\hline NCFO & Net cash flows from operating activities & Worldscope & 0.06 & 0.06 & 0.09 & $(0.63)$ & 0.69 \\
\hline NCFI & Net cash flows from investing activities & Worldscope & 0.04 & 0.04 & 0.11 & $(2.52)$ & 0.55 \\
\hline NCFF & Net cash flows from financing activities & Worldscope & $(0.02)$ & $(0.02)$ & 0.10 & $(1.45)$ & 0.46 \\
\hline
\end{tabular}

\section{Appendix 3}

The dividend-lifecycle relationship using alternative MLDA specifications. This table reports regression based tests of the lifecycle model of dividends using alternative Multiclass Linear Discriminant Analysis (MLDA) specifications. MLDA2 uses sales growth and profitability; MLDA3 uses sales growth, profitability, and RE/TE; MLDA4 uses sales growth, profitability, RE/TE, and size; MLDA5 uses sales growth, profitability, RE/TE, age, and size. Panel A reports the number of firms in each lifecycle stage and the percentage of overlapping firms in each lifecycle stage according to MLDA and Dickinson (2011, DK). 1810 firm-year observations are included in each regression.

Panel A: Comparison between Dickinson (2011) lifecycle and alternative MLDA lifecycle specifications

\begin{tabular}{lllll}
\hline & \multicolumn{2}{l}{ Lifecycle stage } & & \\
\cline { 2 - 5 } & Introduction & Growth & Mature & Shake-out/decline \\
\hline Dickinson (2011) & 152 & 412 & 760 & 486 \\
MLDA2 & 364 & 332 & 639 & 475
\end{tabular}




$\begin{array}{lllll}\text { \% same as DK (2011) } & 34.87 & 25.24 & 46.97 & 31.89 \\ \text { MLDA3 } & 389 & 370 & 561 & 490 \\ \text { \% same as DK (2011) } & 40.79 & 29.13 & 42.11 & 32.51 \\ \text { MLDA4 } & 378 & 405 & 553 & 474 \\ \text { \% same as DK (2011) } & 48.68 & 33.50 & 42.63 & 33.95 \\ \text { MLDA5 } & 414 & 398 & 550 & 448 \\ \text { \% same as DK (2011) } & 47.37 & 32.28 & 42.11 & 31.28\end{array}$

Panel B: Regression based tests of the dividend-lifecycle model using alternative MLDA specifications Dependent variable is div-sales (\%)

\begin{tabular}{|c|c|c|c|c|}
\hline & & & & \\
\hline & MLDA2 & MLDA3 & MLDA4 & MLDA5 \\
\hline Growth & $0.030(0.61)$ & $0.216 * * *(2.90)$ & $0.214 * * *(3.32)$ & $0.096(1.41)$ \\
\hline Mature & $0.160 * *(2.14)$ & $0.363 * * *(5.02)$ & $0.372 * * *(5.05)$ & $0.226 * * *(2.93)$ \\
\hline Shake-out/decline & $0.106 * *(2.15)$ & $0.199 * * *(4.12)$ & $0.223 * * *(4.39)$ & $0.042(0.74)$ \\
\hline $\mathrm{RE} / \mathrm{TE}$ & $0.425 * * *(4.63)$ & & & \\
\hline Industry and time dummies & Included & Included & Included & Included \\
\hline Controls & Included & Included & Included & Included \\
\hline R-Squared & 0.308 & 0.246 & 0.247 & 0.237 \\
\hline Growth vs. mature & $* *$ & $*$ & $* *$ & $*$ \\
\hline Growth vs. shake-out/decline & $*$ & & & \\
\hline \multirow[t]{2}{*}{ Mature vs. shake-out/decline } & & $* *$ & $* *$ & $* *$ \\
\hline & \multicolumn{4}{|c|}{ Dependent variable is div-assets (\%) } \\
\hline Growth & $0.102 * *(2.50)$ & $0.254 * * *(4.66)$ & $0.211 * * *(4.02)$ & $0.106 *(1.93)$ \\
\hline Mature & $0.350 * * *(5.98)$ & $0.502 * * *(8.43)$ & $0.485 * * *(7.84)$ & $0.326 * * *(5.22)$ \\
\hline Shake-out/decline & $0.096 * * *(2.67)$ & $0.147 * * *(4.13)$ & $0.189 * * *(4.61)$ & $0.000(0.01)$ \\
\hline $\mathrm{RE} / \mathrm{TE}$ & $0.338 * * *(4.33)$ & & & \\
\hline Industry and time dummies & Included & Included & Included & Included \\
\hline Controls & Included & Included & Included & Included \\
\hline R-squared & 0.331 & 0.294 & 0.291 & 0.276 \\
\hline Growth vs. mature & $* * *$ & $* * *$ & $* * *$ & $* * *$ \\
\hline Growth vs. shake-out/decline & & $*$ & & $*$ \\
\hline Mature vs. shake-out/decline & $* * *$ & $* * *$ & $* * *$ & $* * *$ \\
\hline
\end{tabular}

\section{References}

Adam, T., Goyal, V., 2008. The investment opportunity set and its proxy variables. J. Financ. Res. 31, 41-63.

Aivazian, V., Booth, L., Cleary, S., 2003. Do emerging market firms follow different dividend policies from U.S. firms? J. Financ. Res. 26, 371-387. Bae, K.H., Goyal, V., 2010. Equity market liberalization and corporate governance. J. Corp. Finan. 16, 609-621.

Baek, J.-S., Kang, J.-K., Park, K., 2004. Corporate governance and firm value: evidence from the Korean financial crisis. J. Financ. Econ. 71, $265-313$.

Banyi, M., Kahle, K., 2014. Declining propensity to play? A re-examination of the lifecycle theory. J. Corp. Finan. 27, 345-366.

Beck, T., Demirguc-Kunt, A., Laeven, L., Maksimovic, V., 2006. The determinants of financing obstacles. J. Int. Money Financ. 25 , $932-952$.

Black, B., Jang, H., Kim, W., 2006. Predicting firms' corporate governance choices. Evidence from Korea. J. Corp. Finan. 12, 660-691.

Black, B., de Carvalho, A.G., Khanna, V., Kim, W., Yurtoglu, B., 2014. Methods for multicountry studies of corporate governance: evidence from the BRIKT countries. J. Econ. 183, 230-240.

Botosan, C., 1997. Disclosure level and the cost of equity capital. Account. Rev. 72, 323-349.

Brockman, P., Unlu, E., 2009. Dividend policy, creditor rights, and the agency costs of debt. J. Financ. Econ. 92, $276-299$.

Brockman, P., Unlu, E., 2011. Earned/contributed capital, dividend policy, and disclosure quality: an international study. J. Bank. Financ. $35,1610-1625$.

Campbell, G., Turner, J., 2011. Substitutes for legal protection: corporate governance and dividends in Victorian Britain. Econ. Hist. Rev. 64, $571-597$.

Chay, J.B., Suh, J., 2009. Payout policy and cash-flow uncertainty. J. Financ. Econ. 93, 88-107.

DeAngelo, H., DeAngelo, L., Stulz, R., 2006. Dividend policy and the earned/contributed capital mix: a test of the life-cycle theory. J. Financ. Econ. 81, 227-254.

Denis, D., Osobov, I., 2008. Why do firms pay dividends? International evidence on the determinants of dividend policy. J. Financ. Econ. 89, 62-82.

Dickinson, V., 2011. Cash flow patterns as a proxy for firm life-cycle. Account. Rev. 86, 1969-1994.

Doidge, C., Karolyi, G., Stulz, R., 2004. Why are foreign firms listed in the U.S. worth more? J. Financ. Econ. 71, $205-238$.

Doidge, C., Karolyi, G., Stulz, R., 2007. Why do countries matter so much for corporate governance? J. Financ. Econ. 86, 1-39.

Faff, R., Kwok, W., Podolski, E., Wong, G., 2016. Do corporate policies follow a life-cycle? J. Bank. Financ. 69, 95-107.

Fama, E., French, K., 2001. Disappearing dividends: changing firm characteristics or lower propensity to pay? J. Financ. Econ. 60 , 3-43.

Gan, J., Lemmon, M., Wang, M., 2013. Can Firms Build Capital-market Reputation to Substitute for Poor Investor Protection? Evidence From Dividend Policies. Hong Kong University of Science and Technology (working paper).

Grullon, G., Michaely, R., Benartzi, S., Thaler, R., 2005. Dividend changes do not signal changes in future profitability. J. Bus. 78, 1659-1682.

Gul, F., Kealey, B., 1999. Chaebol, investment opportunity set and corporate debt and dividend policies of Korean companies. Rev. Quant. Finan. Acc. 13, 401-416. Hwang, L.-S., Kim, H., Park, K., Park, R.S., 2013. Corporate governance and payout policy: evidence from Korean business groups. Pac. Basin Financ. J. 24, 179-198. John, K., Knyazeva, A., Knyazeva, D., 2015. Governance and payout precommitment. J. Corp. Finan. 33, $101-117$.

Kim, J.-B., Yi, C.H., 2015. Foreign versus domestic institutional investors in emerging markets: who contributes more to firm-specific information flow. Chin. J. Acc. Res. 8, 1-23.

La Porta, R., Lopez-de-Silanes, F., Shleifer, A., Vishny, R., 1998. Law and finance. J. Polit. Econ. 106 (6), $1113-1155$.

La Porta, R., Lopez-de-Silanes, F., Shleifer, A., Vishny, R., 2000. Agency problems and dividend policy around the world. J. Financ. 55, 1-33.

Masters, N., Faff, R., Pathan, S., 2016. Financial constraints and dividend policy. Aust. J. Manag. 41, 484-507. 
Miller, D., Friesen, P., 1984. A longitudinal study of the corporate lifecycle. Manag. Sci. 30, 1161-1183.

Owen, S., Yawson, A., 2010. Corporate life cycle and M \& A activity. J. Bank. Financ. 34, 427-440.

Petersen, M., 2009. Estimating standard errors in finance panel data sets: comparing approaches. Rev. Financ. Stud. 22, 435-480.

Sengupta, P., 1998. Corporate disclosure quality and the cost of debt. Account. Rev. 73, 459-474.

Shao, L., Kwok, C., Guedhami, O., 2013. Dividend policy: balancing interests between shareholders and creditors. J. Financ. Res. 36, 43-66.

Von Eije, H., Megginson, W., 2008. Dividends and share repurchases in the European Union. J. Financ. Econ. 89, 347-374. 